\title{
COMMENTS ON THE ECOLOGY OF GRASS GRUB AND PORINA CATERPILLAR
}

\author{
R. P. POtTINGER \\ Lincolr: College
}

\section{INTRODUCTION}

The овлест of this paper is to discuss the ecology of grass grub, Costelytra zealandica White, and porina, Wiseana cervinata (Walker), New Zealand's most important pastoral insect pests, and to survey what has been achieved in ecological understanding of these insects. The biology and ecology of either or both insects have previously been reviewed by Dumbleton (1942), Miller (1945), Kelsey (1951a, b) and Hoy (1963). The lack of fundamental biological information on grass grub (and this is equally applicable to porina caterpillar) and the need for longterm team studies were stressed, although little sustained, co-ordinated research has since eventuated.

Examination of the literature clearly indicates that the lack of fundamental ecological research on these pasture pests is directly due to the introduction of organochlorine insecticides, particularly DDT, to control both porina and grass grub. These insecticides proved cheap, persistent in soil, relatively safe to handle and easy to apply (Kelsey and Hoy, 1950; Kelsey 1951a, b, 1952, 1959). DDT was so effective that it led to complacency, in spite of the warning by Miller (1945) that in his view no single control would suffice. There was failure to anticipate:

(1) Development of insect resistance. to insecticides.

(2) Possible alteration of tolerance limits for insecticides in foodstuffs, by countries importing New Zealand produce.

(3) Failure of DDT to be effective in certain soils.

(4) The need for fundamental knowledge, in case the efficacy of DDT and related insecticides diminished, and new methods had to be found. 


\section{GRASS GRUB}

The life-history of grass grub adapted from Kelsey (1951a) and Dumbleton (1942) for coastal Canterbury is given in Fig. 1A. This figure is largely based on observations and urgently requires experimental proof in at least four regions, in each Island, over a period of several years. The observations of Miller (1921, 1945) indicate that the life-cycle of grass grub commences about one month earlier at Nelson than Kelsey (1951a) found in Canterbury. Kain (1968) states that flights commence in October in Hamilton and notes that development of grass grub there is one month ahead of Taupo. He has also observed marked differences in development, of up to two weeks between different aspects or soil type within the same paddock. All authors agree that there are three larval instars.

The sex ratios of third instar larvae, pupae and beetles are not significantly different from 1 :1 (Kain, 1958). However, the males tend to develop and emerge ahead of females each season (Kelsey, 1951a; Kain, 1968). After development is complete, the beetles move from the pupal cell to a position just below the base of the sward and may remain there for some time. The males flv earlier at night and this results in the females being mated almost as soon as they emerge from the soil (Kelsey, 1951a). Most beetles emerge in the first hour of darkness, although Kain (1968) has found that $25 \%$ of the population emerge from 1 a.m. to 6 a.m. Kelsey (1951a) states that the females seldom fly, and only if thev are not mated do they move to feeding sites where mating occurs. He claims that onlv $5 \%$ of the females fly from areas in which they emerge and that this is the main reason why grub damage increases within a paddock over several years until a peak is reached. Kain observed that only beetles which emerge in the first hour each night fly and that most females fly after making their first oviposition in the soil. He found 'that males tend to fly closer to the ground than females, in search of mates, whilst females tend to fly higher and in a more directional manner to feeding sites. Kelsey has found in Canterbury that flight does not occur 'when temperatures are lower than $49^{\circ} \mathrm{F}$, when there is light or heavy rain, or the wind exceeds $10 \mathrm{mph}$, although beetles will emerge and feed under these conditions. The attraction to 75 watt white lights, has been investigated bv Kelsey (1967). Kelsey (1951b) found that in the first half of the flight season only $5 \%$ of the catch were females, whilst in 


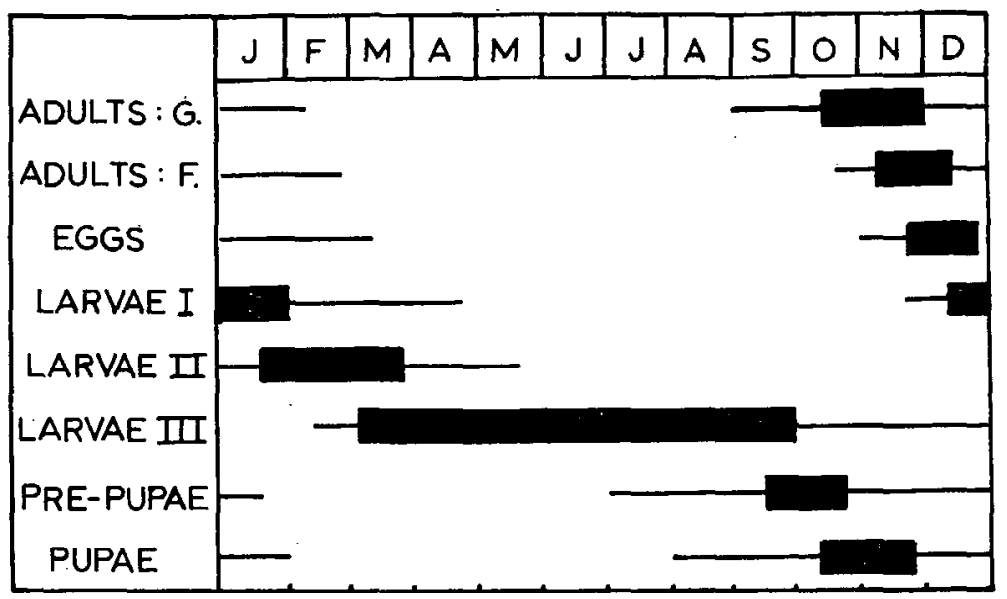

A. LIFE CYCLE COSTELYTRA ZEALANDICA.

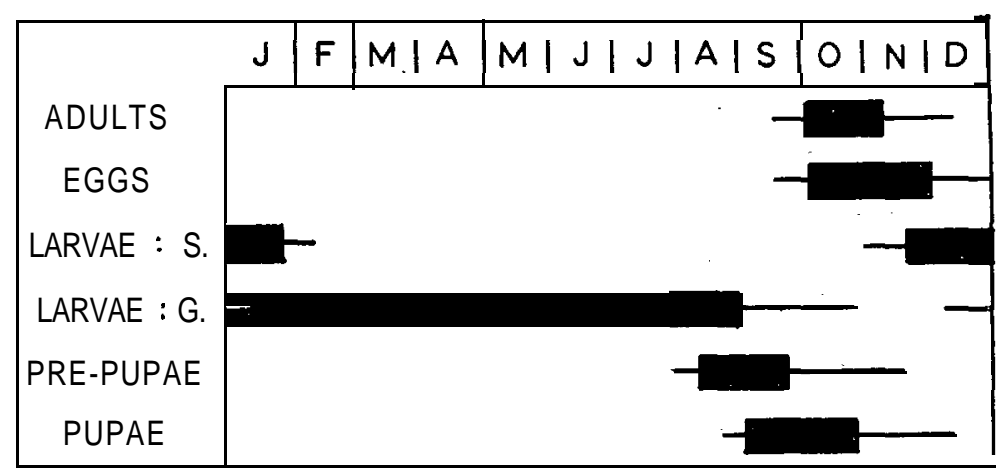

B. 'LIFE CYCLE WISEANA CERVINATA.

FIG. 1: Life histories of grass grub and porina in Canterbury.

the latter half $25 \%$ of the catch were females. He concluded from this that lights and fires did not offer a practicable means of control. The dispersive mechanisms of the beetles are not understood.

Little work has been done on the food of the beetles. Kelsey (1951a) states that they prefer leaves and flowers of deciduous shrubs, trees, all clovers and the foliage of cruciferous plants. He notes that feeding occurs after 
mating and is normally confined to the neighbourhood of mating sites. Nothing is known about the attraction of beetles to food plants, although Osborne and Hoyt (1968) have found that a component of the distillate of elder flowers (Sambucus nigra L.) is highly attractive to females.

The beetles are sexually mature on emergence and mating takes place immediately, in the soil (Kain 1968), on pasture or on feed trees and shrubs (Kelsey 1951a, Kain 1968). The eggs are laid 2 to 9 days after mating (Kain, 1968), after 7 days (Kelsey, 1951b) or 7 to 16 days later '(Miller, 1945). The females usually oviposit twice, but up to five ovipositions can occur. Kain found that $72 \%$ of the eggs are laid in the first oviposition and $94 \%$ in the first two ovipositions, and that feeding is necessary to ensure subsequent ovipositions. The eggs are laid in clusters 3 to 7 in. below the surface, according to the degree of soil moisture. Kelsey has found the numbers range from 3 to 40, with a mean of 22 eggs per cluster.

Kelsey also notes there is a period of 4 to 9 days between successive ovipositions and the maximum fecundity of a female to be 52 .

No one has clearly indicated the longevity of the beetles, although Fenemore (1966) suggests they live for two to three weeks.

Kelsey (1957, 1968) has investigated the site requirements of ovipositing females on artificially infested plots and found a highly significant preference for soils covered with pasture, although pasture density and length did not affect this preference. This study was not carried'out until the autumn and hence failed to consider any mortality of juvenile stages due to treatment differences and the possibility of surface migration of larvae between treatments. Generally females lay eggs in pastures or soils rich in organic matter (Miller, 1945), but, in dry years particularly, they will ovinosit in cultivated areas in preference to hard turf (Kelsey, 1951a).

The eggs are able to withstand drastic extremes of alternate drying: and wetting, but must absorb free water from the soil ( $25 \%$ of their bulk) before they hatch after an incubation period of 16 to 21 days (Kelsey. 1951a). There is an obvious need to know what degree of moisture eggs can tolerate, and whether the beetles prefer a particular soil $\mathrm{pF}$ before ovipositing.

The first stage grubs on hatching from the eggs feed in the immediate vicinity of roots. Kelsey has recorded mean larval populations 'in excess of 150 per square foot. The second stage grubs are commonly found in the top 
2in. of soil, but move down to a depth of $3 \mathrm{in}$. and change to the third instar. In this stage they feed on roots and most are found in the top inch of soil while actively feeding. From the end of June on, they eat less, their bodies fill with yellowish fat, they void their gut contents and move down the soil to a depth of 3 to $10 \mathrm{in}$., and in August and September the majority prepare their earthen pupation cells. Miller (1945) has noted that, depending on the severity of the soil climate during the winter months, the grubs may hibernate deep in the soil, ascending in spring to complete their feeding. This phenonomen has not been reported elsewhere. Dumbleton (1942) quotes Miller as having shown experimentally that half-grown larvae could develop to maturity in soil well supplied with humus and no living roots. This finding has important practical implications and warrants further research. There is no information available on the water relations of the larvae, the effect of different soil types on them, or the vertical or lateral dispersion of them. No one knows how much food they eat, the effect of different foods on the rate of growth and adult fecundity, or their effects on soil fertility, drainage and aeration, although Yaacob (1967) has shown that they form part of the chain in the breakdown of organically fixed nitrogen into mineralized forms.

The'effect of irrigation on grass grub populations merits close consideration. Kelsey (1951) is of the opinion that irrigation water does not saturate the soil long enough to drown grubs, and suggests that more vigorous root growth enables irrigated pastures to withstand a higher population than dryland pastures. Irrigation water, however, may have indirect effects for it may favour disease epidemics, such as bacterial milky disease; or induce the grubs to feed closer to the surface in autumn and early winter thus placing them in reach of predatory birds, or expose the grubs to the crushing effects of sheep hooves which Kelsey suggests are more potent than a heavy roller.

$A$ wide range of insect and vertebrate predators, parasites and pathogenic organisms have been recorded attacking grass grub. Their importance is, however, mere speculation until population dynamics studies to determine whether or not they can regulate population levels from one generation to another are completed. Pottinger (1967) has indicated that this could take a decade or more. Dumbleton (1945a) has discussed bacterial and nematode parasites of grass grub, and in 1942 reviewed biotic factors affecting it. Since this time both Kelsey (1951a) 
and Hoy (1963) have briefly reviewed biological controlling agents. Kelsey and Hoy (1950) and Kelsey (1951a) state that they believe cannibalism of the second and third stage larvae is the main natural 'factor limiting grass grub populations. Kelsey measured a reduction in a grass grub population from 141 to 8 per square foot and, finding few obvious mortalities, suggested cannibalism was the cause. This matter obviously warrants further investigation.

\section{PORINA}

The life-history of W. cervinata for coastal Canterbury is given in Fig. 1B. This figure is a modification of the life-history observed by Dumbleton and Dick (1942) at Seddon and incorporates observations made by Dumbleton (1945b), Dick (1945), Helson (1967) and the present author. Dumbleton (1945b) suggests that flights commence in mid-September in Wairarapa, late September in $\mathrm{Nelson}$ and Marlborough, early October in Canterbury and North Otago, and later in Southland. A pparently the effect of latitude and altitude, a temperature relationship, is the same for both grass grub and porina. Dick (1945) concluded that soil temperature appeared the principal governing factor on both completion of development and emergence.

Eclosion of the moths occurs within the first hour after sunset each day, although the time is variable, depending on latitude and time of year. Whether other factors such as light or the passage of front'al systems are important is not known. Dick (1945) has described the process of eclosion and mating which occurs on the ground. Both male and female moths fly on the evening of emergence, but are short-lived and do not feed. Dick found the moths live 1 to 4 days as did Dumbleton (1945b) who suggests that the females die earlier than males and shortly after they have laid their eggs. At Lincoln College female moths have been found living as long as nine days and males seven days. Moths do not fly on windy nights or during periods of rain. Dick (1945) concluded that the temperature threshold for flight is low, that there was no correlation between numbers flying and relative humidity, and that catches tend to increase at temperatures above $47^{\circ} \mathrm{F}$. Both Dick (1945) and Dumbleton (1945b) observed that male flight occurs in the first hour following eclosion and that thereafter most of the aerial population is composed of females. In mid-October the males fly within 2 to $3 \mathrm{ft}$ of the ground from 7.00 to 7.30 p.m., in search of females 


\section{$\begin{array}{lllllll}1 & 0 & 8 & \text { PROCEEDINGS } & \text { N.z. GRASSLAND ASSOCIATION }\end{array}$}

which emerge from 7.15 to 7.45 p.m., and cling to the grass blades. Dumbleton (1945b) found from one night's light trapping that the majority of moths (63.3\% females) were caught in the first hour of flight. In contrast, Dick (1945) found $56.8 \%$ of the moths caught between 7 and 8 p.m. were males and observed that moths (presumably males) on the wing prior to darkness were not attracted to light. He found no indication of mass migration of moths apart from one paddock bared of vegetation. The writer has measured both an immigration and emigration of moths which suggest dispersive flights are important in the dynamics and epidemics of this pest. Sufficient female moths migrated into an g-month-old white clover-perennial ryegrass paddock, devoid of any population, and produced a population of caterpillars (mean of 96 one square foot samples on July 3, 1967, 6.86/sq. ft) large enough to destroy the sward. Sampling for eggs on this plot and an undamaged pasture beside it in October, 1967, revealed emigration from the bare to grassed areas. The population means were $24.0 / \mathrm{sq}$. ft for the damaged pasture and 195.0/ sq. $\mathrm{ft}$ for the grazed area.

Little is known about these dispersive flights or the attractiveness of various light sources.

Recently D. G. Kelly at Lincoln College has 'initiated a study to determine the optimal type and wavelength of light, trap, wattage, and distribution of lights within paddocks and their effect on reducing egg and consequently caterpillar numbers. As Kelsey (1951b) observed, however, before the moths are caught the females may lay sufficient eggs to cause damage the next year.

- Dick found that female moths commence oviposition 2 to 30 minutes after mating as they crawl and flutter among the vegetation, and that eggs are not laid on the wing. Dick observed the fecundity of six female moths and found that they produced from 445 to 1,169 eggs each (mean, 756). The writer has found from a larger sample that fecundity is correlated with larval nutrition, moths derived from a starved population producing less than $50 \%$ as many eggs as moths from a well-fed popuIation. The results are given in Table 1.

Porina eggs take 3 to 5 weeks to incubate and hatch. Dumbleton (1945) established that the constant lethal temperature is between 77 and $84^{\circ} \mathrm{F}$, while the threshold level for development is $44^{\circ} \mathrm{F}$. He found that eggs develop most rapidly and with the least mortality in. a saturated atmosphere, especially on a moist substratum, and that 
TABLE 1: RELATIONSHIP OF FECUNDITY TO LARVAL NUTRITION

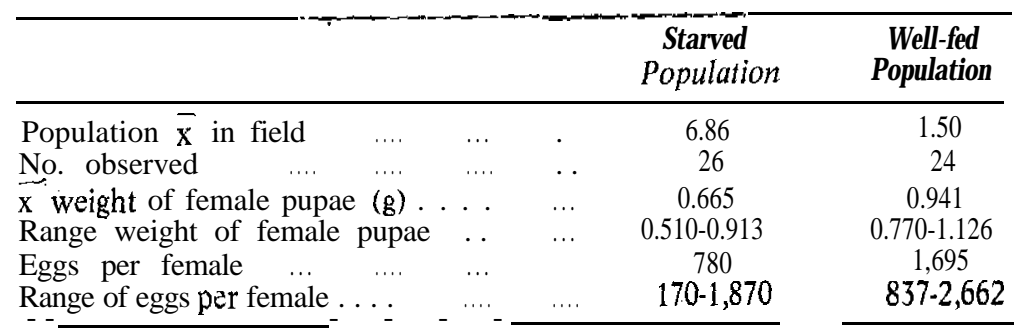

mortality was high if eggs were exposed to humidities bel ow $70 \%$ over the whole or latter half of the incubation period. Dumbleton also established that young caterpillars which live on the surface of the ground for at least four weeks survived longest in a saturated atmosphere. These findings have had tremendous practical application. For instance, it is possible to induce subeconomic porina populations by grazing pastures in October and November so that rank moist conditions conducive to porina survival do not prevail, and farmers now know that it is prudent to inspect pastures which carried rank spring growth for porina each autumn. The number of larval instars is not known. Dumbleton and Dick (1942) used head width measurements to illustrate that the maximum period of porina growth occurs in the February-A pril period which coincides with the maximum period of porina damage to pasture.

A large number of natural enemies attack porina larvae and/ or pupae, but at present one can only speculate on their importance as regulatory factors. It appears from the literature that no natural enemy acts soon enough after pasture damage begins to appear in March to reduce the population to a subeconomic level. Dumbleton (1945b) has reviewed the literature on parasites, predators and diseases. Since this time Eyles $(1965,1966)$ has made observations on three new native parasites and a staphylinid predator. Eyles (1965) states that, although they reduce host numbers, the natural enemies do not control Wiseana spp., probably for the following reasons which could apply equally to grass grub:

(1) The larvae are relatively well protected as they live most of their life underground.

(2) Hyperparasites may reduce the efficiency of some parasites. 
(3) Little is known about the biology of parasites and there is some evidence that tachinids favour grassland near the shelter of scrub. Either the host has moved away from the normal habitat of the parasites, or else the parasites never took a higher toll than they do now.

Dumbleton (1949) has described a gregarine parasite, Diplocystis oxycani Dumbleton, which commonly occurs in larvae, but the relationship to the host is unknown and warrants investigation. $\mathrm{He}$ also states (1945b) that the green muscardine fung,, Is Metarrhizium anisopliae Metchn, may be important in some seasons on some soil types. Latch (1965) considers that this fungus is unlikely to be of much use for biological control of pasture-inhabiting larvae. In July and August, 1967, an epidemic of M. anisopliae induced $84 \%$ mortality on a plot with a mean population of 6.86 larvae per square foot. This population consisted mainly of starved lightweight individuals, whereas another plot beside it with a lower mean population $(1.5 / \mathrm{sq}$. ft) but bigger individuals suffered only a $6 \%$ mortality.

The role of predators has not been investigated. Dumbleton (1945b) pointed out that invertebrate predation of eggs and juvenile larvae may be important, especially in older pastures. We have established that juvenile mortality is exceptionally high and that $W$. cervinata has an inverse J-shaped survival curve, in old and new pastures. Dumbleton also observed that, when infested areas are flooded, porina larvae emerge from their tunnels and are preyed on by seagulls. On the other hand, Kelsey (1951b) claims that in irrigated areas seagulls feed mainly on surface-inhabiting insects and not porina. He notes that caterpillars are in the tops of their tunnels and thus protected from drowning by air bubbles until the water recedes, and remain inaccessible to predators. Porina pupae were easily flooded out of their tunnels, however, and could be easy prey for birds.

\section{COMMENTS AND CONCLUSION}

This review has indicated that knowledge on both pests is mainlv observational in nature, and that little quantitative work has been conducted on any aspect of the biologv. Ecological studies on grass grub and porina are essential, for. as Power (1968) has remarked, all pest control disciplines have a vital ecological content. 
There is little information on sampling procedure and extraction methods, and insufficient is known about the type of distribution of the various stages in the field. Reliable sampling is paramount to any study involving population estimates. Understanding of the population dynamics of both pests is also lacking.

In order to gather such information, long-term plots were established at Lincoln College in 1966, but there is need for replication of these studies as soils, climate, pastures and farm management practices vary within and between regions. Co-operative research between Lincoln College and the Department of Agriculture on the population dynamics of porina and grass grub has been initiated at several centres in New Zealand

There is a need for carefully planned, co-ordinated and inductively based research, and the establishment of priorities because of the limited number of ecologists involved. Steps are now being undertaken to achieve this and overcome the lack of ecological research over the past two decades. The following areas of ecological research on both grass grub and porina are of prime importance to the formulation of optimal control strategy and need to be expanded or established :

(1) Determination of optimal sampling and extraction procedures for population studies, surveys and advisory purposes.

(2) Long-term population dynamics studies.

(3) Differentiation of the stages of closely related Scarabaeid and Hepialid species, to facilitate the accuracy of field work.

(4) Construction of empirically based regional lifehistories, including the determination of the number of porina larval instars.

(5) Behavioural studies on all stages, particularly on the larvae.

(6) Investigation of the role of both porina and grass grub in soil-forming and fertility processes.

(7) A study of soil moisture relationships.

(8) A detailed study of the effect of pasture composition on insects, and, conversely, insects on pasture composition and yield.

(9) A food study including biomass and energy flow studies 
(10) Investigation of farm management practices on population levels.

(11) Detailed examination of the natural enemies, particularly those revealed by population dynamics studies to be important in population regulation.

(12) Correlation of epidemic populations with particular soil types.

\section{ACKN OWLEDGEMENT}

The author wishes to thank W. M. Kain of Ruakura Research Centre, Department of Agriculture, for kindly allowing him to refer to his unpublished paper.

\section{REFERENCES}

Dick, R. D., 1945: N.Z. J. Sci. Tech., 27A: 32-6.

Dumbleton, L. J., 1942: N.Z. J. Sci. Tech., 23A : 305-21.

1945a: N.Z. J. Sci. Tech., 27A: 76-81.

, 1945b: N.Z. J. Sci. Tech., 27A: 114-28.

- 1949: Proc. N.Z. Grassl. Ass., 241-52.

Dumbleton, L. J.; Dick, R. D., 1942: N.Z. J. Sci. Tech., 23A : 284-93.

Eyles, A. C., 1965: N.Z. J. agric. Res., 8: 951-S. , 1966: N.Z. J. agric. Res., 9: 699-703.

Fenemore, P. G., 1966: Proc. N.Z. ecol. Soc., 13: 75-8,

Helson, G. A. H., 1967: Trans. R. Soc. N.Z. Zool., 9: 79-91.

Hoy, J. M., 1963: Proc. N.Z. Weed \& Pest Control Conf., 16: 118-22.

Kain, W. M., 1968: Observations on Costelytra zealandica White within the Central North Island region. Unpubl. paper read at 40th ANZAAS Conf., Christchurch.

Kelsey, J. M., 1951a: N.Z. J. A gric., 83: 113-22.

1951b: N.Z. I. Agric. 83: 195-200.

1952: Proc. N.Z. Grassl. Ass., 14: 58.66

, 1957: N.Z. J. Sci. Tech., 38A: 633-7.

1959: Sheepfarming Annu. 85- 8.

1967: NZ Ent, 4(1): 12-9.

1968: N.Z. L agric. Res.. 11: 206-10.

Kelsey, J. M.; Hoy, I. M., 1950: Proc. N.Z. G rassl. A ss., 12: 88-94.

Latch, G. C. M., 1965: N.Z. I. agric. Res., 8: 384-96.

Miller, D., 1921: N.Z. J. Agric., 23: 199-203 , 1945: N.Z. J. A gric., 70: 51-5.

Osborne, G. 0.; Hoyt, C. P., 1968: N.Z. J. Sci., 11: 137-9.

Pottinger, R. P., 1967: N.Z. agric. Sci., 1 (12): 8-15.

Power, R. J. B., 1968: Proc. N.Z. ecol. Soc., 15: 7-9

Yaacob, 0. bin., 1967: The influence of earthworms, Allolobophora caliginosa Savigny, and grass grubs, Costelytra zealandica White, on the availability of pasture soil nitrogen. M.Agr.Sci. thesis. Lincoln Coll., Univ. of Canterbury. (Lodged in Lincoln Coll. Library.) 


\section{DISCUSSION}

In reply to a question on how to ensure that more research on grass grub and porina control was carried out, Pottinger stated that the co-ordinated research just started was the right step to take, and he felt that both D.S.I.R. and Department of Agriculture were well aware of this. More ecologists were needed in the field, and it was better to train them in New Zealand universities than to import them from overseas. Locally trained people tended to be more interested in the problem.

To a question on the length of exposure to drying necessary to cause mortality to porina, Pottinger replied that no exact time could be given, which again highlighted the need for more detailed research.

Lucerne would stand severe attacks from both grass grub and porina and should be more widely used in areas likely to be badly affected by these pests.

Brougham suggested that worthwhile observations on the pests could be made by other research workers carrying out grazing and mowing trials throughout New Zealand. Pottinger agreed and thought that this would be particularly feasible when a satisfactory system of sampling had been devised to give comparisons. Such a system should shortly be available. The data collected could then be analysed to give more knowledge on population dynamics.

Asked to elaborate on the crushing effect on porina of sheep's feet, Pottinger stated that Kelsey's observations had shown that it was grass grub and not porina that could be affected. Porina seemed to be well adapted to avoid damage from the animals' hooves. In any case, he felt that fairly rapid re-infestation would occur. 